\title{
Competitive Advantages of Lazada Indonesia
}

\author{
Dita Amanah and Dedy Ansari Harahap
}

\begin{abstract}
Lazada Indonesia's competitive advantage as a marketplace in Indonesia is determined in this article. Internal and external factors were identified to analyze the SWOT and the strategies implemented by Lazada. In-depth interviews, observations and documentation studies are used to collect data. All students of the Doctoral Program of Management Science in Universitas Pendidikan Indonesia were respondents of this study. They all 112 respondents. The SWOT analysis results show that in the first quadrant, Lazada implements an aggressive growth strategy in achieving competitive advantage. Existing strengths and opportunities put Lazada in a advantageous position and maximally utilizing external forces to seize opportunities. Lazada is a pioneer of free shipping of goods and services for returning goods from consumers. Lazada is also increasingly expanding its products to fulfill the consumers desires.
\end{abstract}

Index Terms - Competitive Advantage, SWOT Analysis, Aggressive Growth Strategy, Lazada Indonesia

\section{INTRODUCTION}

\section{A. Research Background}

The phenomenon of shopping through internet is become a trend and epidemic. It is supported by the increasing number of internet users in Indonesia. Until March 2017, Internet World Stats recorded the estimated population of Indonesia reached 262 million people with the number of internet users 132 million people. This number puts Indonesia at number 5 as the country with the largest number of internet users in the world after China, India, United States and Brazil. Internet penetration rate in Indonesia until March 2017 reached 50.4\%, a drastic increase from 2016 which recorded 34.1\% [1]. According to Association of Indonesian Internet Service Users[2], majority of internet users are male (52\%) which increase compared to 2015 (49\%). This data shows a change in the phenomenon of gender differences in using the internet. There is a change in the number of internet users by age. In $2015,83.3 \%$ of internet users are under 30 years old, while in 2016 there was a decrease to $44.8 \%$. Based on employment, workers / entrepreneurs are the highest internet users in $2016(62 \%)$. Internet users from urban areas dominate based on access location. In terms of level of education, in 2016, 39\% internet users are high school level, decrease compared to 2013 that is $64.7 \%$. Based on data from the Bolton Consulting Group (BCG), in 2013 the middle class in Indonesia has reached 74 million people and predicted by 2020 will increase to 141 million people or

Published on February 01, 2020.

Dita Amanah, Faculty of Economics, Universitas Negeri Medan, Jalan Willem Iskandar Pasar V Medan Estate, Medan, Indonesia.

(e-mail: ditamnh@yahoo.com)

Dedy Ansari Harahap, Faculty of Economics and Business, Universitas Islam Bandung, Jl. Tamansari No.1, Bandung, West Java, Indonesia.

(e-mail: deanhar@yahoo.com) around $54 \%$ of the total population in Indonesia. This indicates that the potential for the development of electronic commerce is very large in Indonesia. An increasing number of middle class people will certainly lead to higher levels of consumption.

Online business has become a trend in recent years. Many online companies are growing, both new and old companies are turning to online business [3]. The more competitors in the online business, the more competition will be to win the hearts of consumers [4].

Today's consumers tend to make purchases online and become a trend in shopping online. Online shopping is an activity of consumer electronic transactions at online stores through a device that is connected to the internet with various media such as computers, laptops, cellphones and others [5].

Lazada.co.id is one of the online shop operating in Indonesia which is part of the Lazada Group which became the number one online shopping destination in Southeast Asia. Lazada Group operates in Indonesia, Malaysia, Philippines, Singapore, Thailand and Vietnam. Lazada Indonesia was founded in 2012. Being a pioneer in the field of e-commerce, Lazada presents an easy shopping service for consumers and direct access to Southeast Asia's largest consumer database. Lazada offers a variety of products ranging from electronics, books, toys and baby gear, medical devices and beauty products, home appliances, and traveling and sports equipment. Lazada is the third best online store in Indonesia has a competitive advantage that is not owned by competitors.

Proper implementation of the strategy is necessary to achieve business objectives. The applied business strategy must be effective and appropriate in order to compete. The right competitive strategy can be obtained by adjusting the internal strength to the company's external environment. Therefore SWOT analysis is one of the right tools that can be used in determining business strategy to win the competition. The formulation of the problem in this study is how SWOT analysis can be used as a basis in the formulation of strategies to create competitive advantage on Lazada.

\section{B. Research Purposes}

Analyze the accuracy of existing strategies and creating the competitive advantage through SWOT analysis.

\section{Research Advantages}

1. Evaluating internal and external factors of Lazada Indonesia.

2. Determining the precise strategy for Lazada Indonesia. 


\section{LITERATURE REVIEW}

\section{A. SWOT Analysis}

According to Blocher, Chen, \& Lin (2002), SWOT analysis is a systematic procedure to identify the factors that determine the success of the company's internal strengths and weaknesses, as well as external opportunities and threats. Meanwhile, according to Wanti, Taufiqurrahman, \& Rahayu (2014) SWOT analysis is an important strategic planning tool to help planning to compare internal strengths and weaknesses with external opportunities and threats.Stephen P. Robins (2012) explained that SWOT analysis is an analysis which is based on the strength, weakness, opportunities and threat of the environment SWOT analysis (Strengths, Weakness, Opportunity, Threats) is a way to observe the external and internal of marketing environment [9].

The SWOT analysis is based on the compatibility between the company's internal resources and its external situation[10]. Good suitability will maximize the company's strengths and opportunities and minimize weaknesses and threats. Strengths and weaknesses are management factors wholly in management control, where strength is the factors that have been successfully controlled, thus have a positive impact on the organization. While the weakness is a factor that is not successfully managed, thus provide a negative impact for the company. Opportunities are factors that are beyond management's control, but their appearance will provide an opportunity for success for the company if the company has enough power to adapt. Threats are factors that are outside management, but when it appears will threaten the life of the company. Threats are a major obstacle for the company in achieving its current position or desired position. Once weaknesses, strengths, and opportunities and threats can be identified, it will then be processed with strategy formulation with SWOT analysis using EFAS table (External Factor Analysis Summary) and IFAS (Internal Factor Analysis Summary)[11].

Analysis of SWOT is the beginning of the strategic planning and does by a group of expert who assess the organization from a critical perspective [12]. Analysis of SWOT is not a new idea in the business world. This model come from the Harvard Business School [13] and had dominated in the planning of business strategy since the 1950s [14]. Analysis of SWOT which far the most famous, provide two functions: it can be used to identify the internal and external environment[15];[14]. Analysis of SWOT is shortened for Strength, Weakness, Opportunity and Threat. Interestingly, the letter of SWOT produces the interesting sounds, such as rhythm, and had implication for the sequence in which the process must be followed by the party who planned the strategy. To understand the SWOT on the overall of the process of strategic planning, it is important to put these step into a suitable framework. There is a useful model formed by [16] which often used. This model consist of three main areas: analysis of strategy, choice of strategy and implementation of strategy, and all of them are interrelated.

From all of the process of strategic planning, SWOT analysis is preliminary stage but it is a very important step as described by Pashiardis (1996) that identify to the environment is important to effective planning. Besides the external, the situation of internal is also noteworthy. In other words, SWOT analysis not only consist of the speculation, the strength and weakness of the future, but also explained the matter exactly happened [17].

Based on the description above can be concluded that the SWOT analysis is part of the company's strategic planning process[18]. The main thing to emphasize is that in the planning process, an institution needs an assessment of the current state and the future picture that affects the process of achieving the company's goals. With SWOT analysis, the main strength characteristics, additional strength, neutral factors, major weaknesses and additional weaknesses are based on internal and external corporate environment analysis [19].

\section{B. Strategy}

Haris (2013) stated that strategy is a plan that is used to achieve company goal that is to give satisfaction to the customer in exchange to get some profit. In addition, the strategy affects the company's long-term prosperity, especially for five years, and is oriented toward the future. Strategies have multifunctional and multidimensional consequences and need to take into account the external and internal factors facing the company [21]. It is a unified, broad and integrated plan that links the company's strategic advantages with environmental challenges, designed to ensure that the main objectives of the company can be achieved through proper implementation by the organization[22].

The strategy must be formulated through several steps to build the organization's vision and mission going forward, set strategic and financial goals of the company and design strategies to achieve these goals in order to provide the best customer value[23]. These steps are[24]:

1. Identify the environment that the company will enter in the future and determine the company's mission to achieve the vision aspired in that environment.

2. Conduct an analysis of the internal and external environment to measure the strengths and weaknesses as well as opportunities and threats that will be faced by the company in carrying out the mission.

3. Formulate key success factors from the strategies designed based on the previous analysis.

4. Determine measurable goals and targets, evaluate various alternative strategies by considering the resources owned and external conditions faced.

5. Choose the most appropriate strategy for achieving shortterm and long-term goals.

The second step after the formulation of the strategy is done is to plan actions that are making achievement plans (targets) and activity plans (programs and budgets) that are truly in accordance with the direction (vision, mission, goals) and strategies set by the organization[25]. Then the last step is implementation. To ensure the success of a strategy that has been successfully formulated, it must be realized in careful implementation actions. Strategies and other organizational elements must be appropriate, strategies must be observed in the design of organizational culture structures, leadership and human resource management systems. Because the strategy is implemented in a changing environment, successful implementation requires control and evaluation of the implementation. So if necessary, appropriate corrective actions can be taken[26]

The management strategy plays an important role for the company / organization because (1) Gives long-term 
direction to be addressed. (2) Help companies organizations adapt to change. (3) Making companies / organizations more active. (4) Identifying the comparative advantage of a company / organization in an increasingly risky environment. (5) Overlapping activities will be reduced. (6) Reluctance to change from old employees can be reduced.(7) The involvement of employees in changing strategies will further motivate them at the implementation stage. (8) Activities Improving the ability of companies / organizations to prevent the emergence of problems in the future [27].Companies / organizations that adopt good management strategies are expected to create strategies that can be managed and implemented that integrate all decisions and actions in the organization in detail [28].

\section{Competitive Advantages}

Hansen \& Mowen (2002) argue that competitive advantage is to create better customer value at the same or lower cost than competitors or create equivalent value at a lower cost than competitors. A company will have a competitive advantage when it has something more than its competitors in attracting consumers and defending itself against the power of competition that tries to suppress the company. Sources of competitive advantage can be: the best products in the market, providing the most powerful service, providing the cheapest selling price, having the most strategic location, the right technology, the attributes of goods in accordance with the will of consumers, distribute the new products fastest, brand and reputation that has been tested, and provide value of goods greater than the money spent by consumer [30].

The concept of competitive advantage can be introduced one of the most ancient concepts of economics and the evolution the can follow to the presents concept absolute advantage by Adam Smith and theory of comparative advantage provided by Ricardo until the present. Due to this long time, various definitions is presented by scholars for clarify the concept of competitive advantage. Competitive advantage is unique position against for an organization's rivals with the efficient use of resources, it is caused most widely [31]. Competitive advantage collection organization unique features that allows it that better performance than their show competitors and competitors are not easily able to simulate [32]. Competitive advantage for the organization's ability to provide the products its customers that is they know the more valuable of the competitors provide Similar cases [33].

Every company / organization that has the ability obtained through the characteristics and resources to have a higher performance than competitors in the same industry or market, then they already have a competitive advantage [34].The heart of a company / organization's performance in a competitive market is competitive advantage, where they really put generic strategies into their business implementation [35]. Fundamentally, competitive advantage develops from the value created by the company to customers exceeding the costs that the company has sacrificed for its customers [36].So whatever is done by companies that are considered better than competitors, this is called competitive advantage [37].Competitive advantage is represented through actions taken by a company that cannot be carried out by competitors which might be the actions that competitors want [38].

\section{Selection of Competitive Advantage Strategies}

Muhammad (2013) argues that three kinds of generic competitive strategies are applied at the level of strategic business units that is cost leadership, differentiation and focus. In a cost leadership strategy the company seeks to offer goods sold at a lower price than similar goods. To establish a cost advantage strategy, the company is required to overcome a relatively large market share and have a competitive advantage in cost efficiency.

In differentiation strategies the company seeks to produce and market goods with distinct characteristics that ultimately are considered unique and exclusive by the consumer. According to Kotler \& Armstrong (2016) differentiation can be done by companies in five dimensions of product differentiation, service differentiation, personnel differentiation, channel differentiation and image sensitive. If this strategy is successfully implemented, the company can earn greater profits than the industry average and will get high brand loyalty because of the high interest and customer attachment to the goods produced. In a focus strategy the company will select one or several segment groups within an industry then they will develop strategies appropriate for that segment that can not be served by other competitors with broader market coverage. Through the optimization of this strategy, companies that choose a focused strategy will gain competitive advantage in certain market segments even though they have no competitive advantage in the industry as a whole.There are several strategies towards competitive advantage [41]:

- A cost strategy, where producers set prices for products / services that are cheaper for customers than competitors, reduce the costs of suppliers or increase the costs of competitors to remain in the industry.

- Differentiation strategy, in which the company develops ways to differentiate products / services from competitors so that customers use products / services because of unique benefits or features.

- Innovation strategies are introducing unique products / services or making radical changes in business processes that cause fundamental changes in business management.

- Growth strategy where the company develops significant production capacity, expands into global marketing, diversifies new products / services or integrates into related products / services.

- Alliance strategies in which the company forms new business relationships and alliances with customers, suppliers, competitors, consultants and others.

\section{METHODOLOGY}

\section{A. Types of Research}

This study used a descriptive qualitative. Internal factors analyzed are the strengths and weaknesses of Lazada and external factors are the opportunities and threats that are expected to be useful in formulating strategies to achieve competitive advantage.

\section{B. The Samples}

The sample is all students of doctoral program of management science in Universitas Pendidikan Indonesia who have made purchases at the online store Lazada that is 112 respondents. 


\section{Data Collection Technique}

Data collected by questionnaires, observation, interview.

\section{Data Analysis Technique}

The method of interpretative analysis is used as a data analysis technique on the basis of theories that support and have a connection with research problems and serves as an explanation of the analysis. The steps used in data analysis techniques are (1) Collecting and analyzing all data that relevant to the problems studied, (2) Analyzing resources by comparing the internal factors of the company that is strengths, and weaknesses with external factors such as opportunities and threats by utilizing the model used as a strategy formulation of the SWOT matrix consisting of the IFAS matrix and the EFAS matrix,(3) Identify the variables that can create competitive advantage in Lazada using SWOT analysis (strengths, weaknesses, opportunities, and threats), (4) Make conclusions and suggestions.

\section{RESULTS, DISCUSSIONS, IMPLICATIONS}

\section{A. Results}

IFAS Lazada Matrix

\begin{tabular}{|c|c|c|c|}
\hline No. & Strengths & No. & Weaknesses \\
\hline 1. & Offer a very wide range of products & 1. & Items can not be held directly \\
\hline 2. & Very easy to find in search engines & 2. & $\begin{array}{l}\text { Products sometimes do not match with what } \\
\text { consumer want / different from that shown }\end{array}$ \\
\hline 3. & $\begin{array}{l}\text { Site is very responsive, easy to use, interesting } \\
\text { and space for ad arranged neatly }\end{array}$ & 3. & $\begin{array}{l}\text { Limit time of ordered product payment is too } \\
\text { short }(1 \times 24 \text { hour })\end{array}$ \\
\hline 4. & Delivery of goods ordered for free & & \\
\hline 5. & $\begin{array}{l}\text { Transactions between buyers and sellers are done } \\
\text { quickly, easily and cheaply. }\end{array}$ & & \\
\hline 6. & Various payment systems & & \\
\hline 7. & Own delivery service & & \\
\hline 8. & Offer the latest and best products & & \\
\hline 9. & $\begin{array}{l}\text { Number of employees who are very adequate and } \\
\text { qualified }\end{array}$ & & \\
\hline 10. & An extensive warehouse & & \\
\hline 11. & Free goods return service & & \\
\hline 12. & Fast product delivery system & & \\
\hline
\end{tabular}

EFAS Lazada Matrix

\begin{tabular}{|c|c|c|c|}
\hline No. & Opportunities & No. & Threats \\
\hline 1. & $\begin{array}{l}\text { Become a top website that is often visited by } \\
\text { people of Indonesia }\end{array}$ & 1. & More online shops are emerging as competitors \\
\hline 2. & $\begin{array}{l}\text { Visitor Lazada is a loyal customer, where the } \\
\text { average time spent to visit this website is about } 7 \\
\text { minutes which is SEO (Search Engine } \\
\text { Optimization) is high enough, thus not } \\
\text { impossible Lazada will be as strong as Amazon }\end{array}$ & 2. & The emergence of fraud \\
\hline 3. & The largest online shop in Southeast Asia & 3. & It is feared the creation of a fake website \\
\hline 4. & $\begin{array}{l}\text { Conduct site promo on various other sites } \\
\text { (Lazada always appear when internet users use } \\
\text { internet) }\end{array}$ & 4. & $\begin{array}{l}\text { Competition price, quality and competition } \\
\text { globally }\end{array}$ \\
\hline 5. & $\begin{array}{l}\text { Increase in revenue and internet users will } \\
\text { increase the market potential of Lazada. }\end{array}$ & 5. & $\begin{array}{l}\text { There is no guarantee that e-commerce } \\
\text { transactions free from destruction / data } \\
\text { manipulation and will certainly impact on the } \\
\text { development of economic activity. }\end{array}$ \\
\hline
\end{tabular}

IFE Lazada Matrix Weighted Table

\begin{tabular}{|c|c|c|c|c|}
\hline No. & Strengths & Weight & $\begin{array}{l}\text { Relative } \\
\text { Weight }\end{array}$ & Explanation \\
\hline 1. & Offer a very wide range of products & 3 & 0,07 & Important \\
\hline 2. & Very easy to find in search engines & 2 & 0,05 & Less important \\
\hline 3. & $\begin{array}{l}\text { Site is very responsive, easy to use, interesting and space for } \\
\text { ad arranged neatly }\end{array}$ & 1 & 0,02 & Not important \\
\hline 4. & Delivery of goods ordered for free & 4 & 0,10 & Very important \\
\hline 5. & $\begin{array}{l}\text { Transactions between buyers and sellers are done quickly, } \\
\text { easily and cheaply. }\end{array}$ & 3 & 0,07 & Important \\
\hline 6. & Various payment systems & 2 & 0,05 & Less important \\
\hline
\end{tabular}



7. Own delivery service
$4 \quad 0,10$
8. Offer the latest and best products
0,07
Very important
9. Number of employees who are very adequate and qualified
0,05 Important
10. An extensive warehouse
$\begin{array}{ll}1 & 0,02 \\ 3 & 0,07\end{array}$
11. Free goods return service
$\begin{array}{ll}1 & 0,02 \\ 3 & 0,07\end{array}$
Less important
Not important Important
12. Fast product delivery system
40,10
Very important

\begin{tabular}{|c|c|c|c|c|}
\hline No. & Weaknesses & Weight & $\begin{array}{l}\text { Relative } \\
\text { Weight }\end{array}$ & Explanation \\
\hline 1. & Items can not be held directly & 4 & 0,10 & Very important \\
\hline 2. & $\begin{array}{l}\text { Products sometimes do not match with what consumer want } \\
\text { / different from that shown }\end{array}$ & 3 & 0,07 & Important \\
\hline \multirow[t]{2}{*}{3.} & $\begin{array}{l}\text { Limit time of ordered product payment is too short (1x24 } \\
\text { hour) }\end{array}$ & 3 & 0,07 & Important \\
\hline & Total & 42 & 1 & \\
\hline
\end{tabular}

EFE Lazada Matrix Weighted Table

\begin{tabular}{llccc} 
No. & \multicolumn{1}{c}{ Opportunities } & Weight & $\begin{array}{c}\text { Relative } \\
\text { Weight }\end{array}$ & Explanation \\
\hline 1. & $\begin{array}{l}\text { Become a top website that is often visited by people of } \\
\text { Indonesia }\end{array}$ & 3 & 0,09 & Important \\
2. $\quad \begin{array}{l}\text { Visitor Lazada is a loyal customer, where the average time } \\
\text { spent to visit this website is about 7 minutes which is SEO } \\
\text { (Search Engine Optimization) is high enough, thus not }\end{array}$ & 4 & 0,13 & Very important \\
$\quad \begin{array}{l}\text { impossible Lazada will be as strong as Amazon } \\
\text { The largest online shop in Southeast Asia }\end{array}$ & 4 & 0,13 & Very important \\
4. & $\begin{array}{l}\text { Important } \\
\text { Conduct site promo on various other sites (Lazada always }\end{array}$ & 3 & 0,09 & Important
\end{tabular}
market potential of Lazada

\begin{tabular}{|c|c|c|c|c|}
\hline No. & Threats & Weight & $\begin{array}{c}\text { Relative } \\
\text { Weight }\end{array}$ & Explanation \\
\hline 1. & More online shops are emerging as competitors & 4 & 0,13 & Very important \\
\hline 2. & The emergence of fraud & 3 & 0,09 & Important \\
\hline 3. & It is feared the creation of a fake website & 4 & 0,13 & Very important \\
\hline 4. & Competition price, quality and competition globally & 2 & 0,06 & Less important \\
\hline \multirow[t]{2}{*}{5.} & $\begin{array}{l}\text { There is no guarantee that e-commerce transactions free } \\
\text { from destruction / data manipulation and will certainly } \\
\text { impact on the development of economic activity. }\end{array}$ & 2 & 0,06 & Less important \\
\hline & Total & 32 & 1 & \\
\hline
\end{tabular}

Analysis SWOT of Lazada

\begin{tabular}{|c|c|c|c|}
\hline Internal Factors & Weight & Ranking & Score \\
\hline \multicolumn{4}{|l|}{ Strengths } \\
\hline Offer a very wide range of products & 0,07 & 4 & 0,28 \\
\hline Very easy to find on search engines & 0,05 & 2 & 0,10 \\
\hline $\begin{array}{l}\text { Site that is very responsive, easy to use, interesting and space for ad } \\
\text { arranged neatly }\end{array}$ & 0,02 & 2 & 0,04 \\
\hline Delivery of goods ordered for free & 0,10 & 4 & 0,40 \\
\hline $\begin{array}{l}\text { Transactions between buyers and sellers are done quickly, easily and } \\
\text { cheaply. }\end{array}$ & 0,07 & 2 & 0,14 \\
\hline Various payment systems & 0,05 & 2 & 0,10 \\
\hline Own delivery service & 0,10 & 1 & 0,10 \\
\hline Offer the latest and best products & 0,07 & 3 & 0,21 \\
\hline Number of employees who are very adequate and qualified & 0,05 & 2 & 0,10 \\
\hline An extensive warehouse & 0,02 & 1 & 0,02 \\
\hline Free goods return service & 0,07 & 1 & 0,07 \\
\hline Fast product delivery system & 0,10 & 1 & 0,10 \\
\hline Total of Strengths & & & 1,66 \\
\hline
\end{tabular}




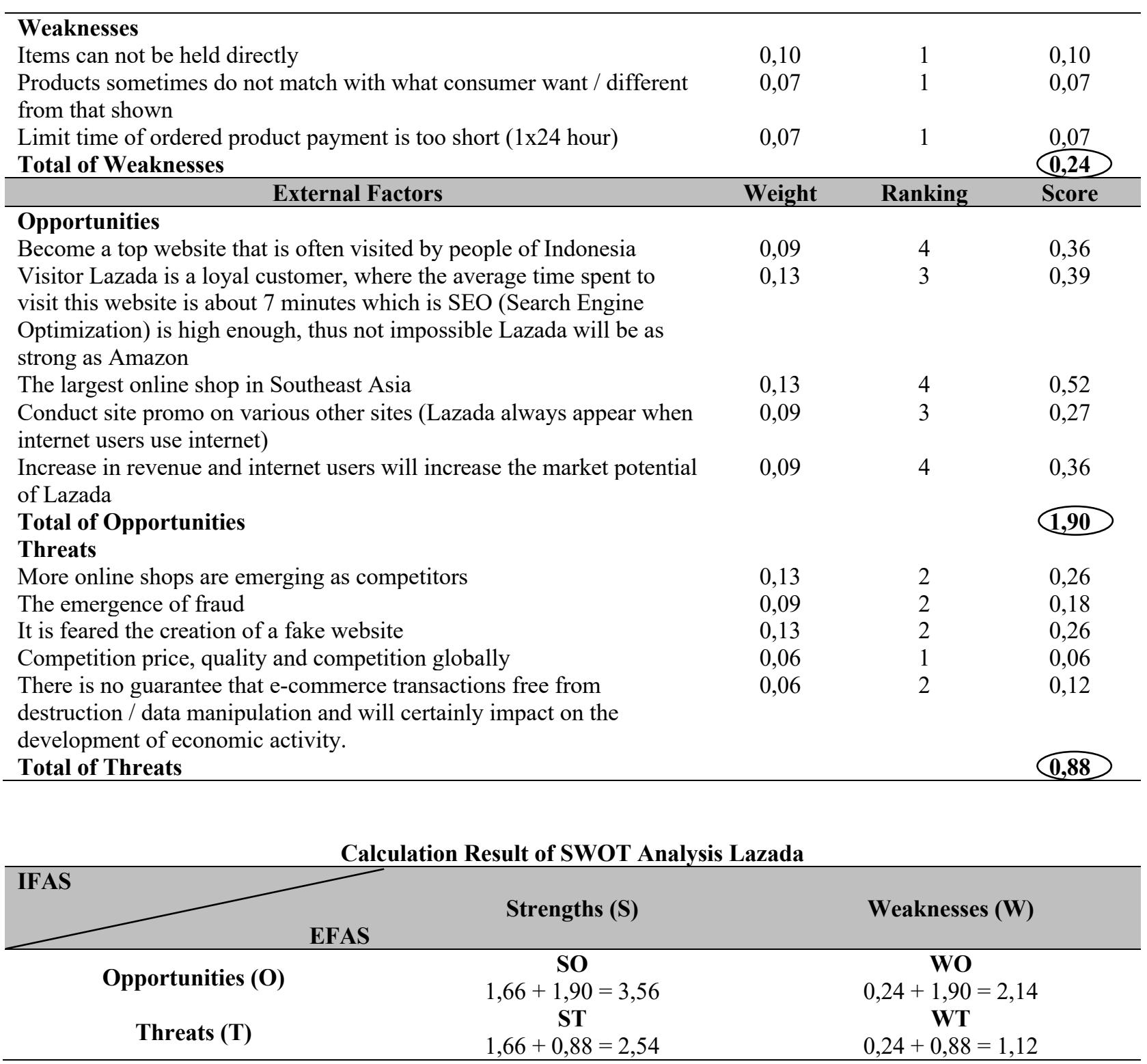

Diagram of SWOT Analysis Lazada

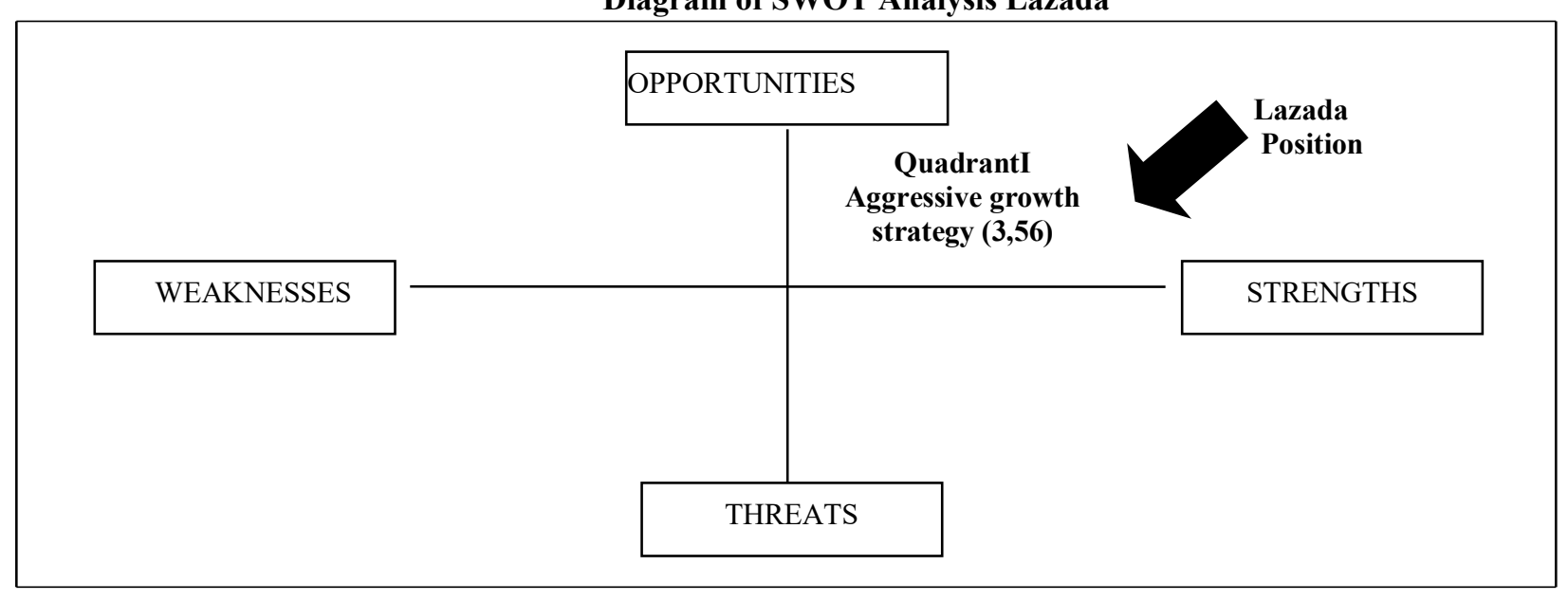

\section{B. Discussions}

Strategy analysis for all situations (SO, WO, ST, WT) are as follows:

\section{WO Strategy}

1. Security both for internal Lazada and for customers should be improved to anticipate fraud and forgery issues.
1. Keep forward freight forwarding for free.

2. Keep forward the unfit return of goods for free. 3. Add product offerings. 
2. Price and quality of products need to be reviewed to 4. Add the latest and greatest product offerings. be adjusted to the majority of the income of the people 5. Expanding into Asia of Indonesia.

WT Strategy $\quad$ ST Strategy

1. The time limit of payment should be longer 1. Delivery of product to be faster. (extended).

2. Products received by customers should match those displayed on the website.

3. Websites display should be easier to understand and easy to use by customers.

2. Must have adequate warehouse to place stock of products.

3. Employees should have a good knowledge of the product.

4. Website appearance should be more interesting.

The result of SWOT analysis shows that there is significant development (score of 1.90 for internal factor and score 2,87 for external factor). Associated with the analysis for each quadrant and the resulting strategy, then Lazada Indonesia is in a very favorable position with a score of 3.56 for a combination of strength and opportunity factors. This means that Lazada Indonesia can implement aggressive growth strategies in creating competitive advantage [42]. Maintaining a free delivery system and increasing the number of visitors to the Lazada site by offering more attractive web designs, more diverse products, more competitive pricing and always listening to customer and visitor comments are essential to continue and improve. Thus it will create a better sense of visiting this online store and may even make a decision to buy [43]. Strategy formulation and implementation is an important task that managers need to do in each company [44]. Strategic management is a process of improving and analyzing internal and external environments aimed at helping companies to clearly define vision and mission statements through three stages: formulation, implementation and evaluation of strategies [45]. Every planning process at the corporate, business and functional levels requires a thorough environmental analysis [46].

Hill \& Westbrook (1997) stated that each company performs various approaches and activities to determine the position of a company within a particular industry. A tool that is always used is SWOT analysis. SWOT stands for S (strength), $\mathrm{W}$ (weakness), $\mathrm{O}$ (opportunity), $\mathrm{T}$ (threat). SWOT analysis is a simple and practical tool, hence many companies have accepted it as a strategy management tool [48]. Environmental changes may lead the company's strategy also changed [49]. In order to survive, the company must utilize competence, maintain good relationships with stakeholders and prioritize customers by delivering value above the average competitors [43].

\section{Research Implications}

Lazada Indonesia can perform various strategies that are beneficial for business progress and also fulfill the needs and desires of consumers. If this strategy is properly managed, it will be a distinct advantage for Lazada Indonesia.The results of the SWOT analysis identified all strengths, weaknesses, opportunities, threats from Lazada Indonesia's internal and external factors. With this result Lazada is expected to be able to understand well the strengths and opportunities to minimize weaknesses and threats. Even though Lazada is in a favorable position, it must be sensitive to reading changes and trends in market developments, so that Lazada can see new opportunities in the market where the company can operate profitably and anticipate any new threats that occur in the business environment.
Currently Lazada is among the most successful companies because it is able to create the highest customer value and maintain it. However, potential threats remain that can be challenges or obstacles in achieving profit and creating value to customers. So threats must always be identified as early as possible and if Lazada has successfully identified the main threats and opportunities, Lazada can describe the nature of the attractiveness of their business as a whole.It takes expertise to be able to successfully seize opportunities and an evaluation of strengths and weaknesses must be done periodically for example by examining the capabilities of marketing, finance, production, organization and all factors contained in the business. From there each factor can be drawn and analyzed whether these factors are the main strengths, minor strengths, neutral factors, minor weaknesses or major weaknesses.

\section{CONCLUSIONS, LIMITATION AND RECOMMENDATIONS}

\section{A. Conclusions}

Based on the results of SWOT analysis, Lazada Indonesia has enormous potential for more advanced in Indonesia. Being in a very favorable position makes Lazada Indonesia able to implement aggressive growth strategy. Competition with similar companies certainly persists and continues to react but if managed well through continuous evaluation of the needs and wants of consumers, it will create competitive advantage and ultimately contribute to customer satisfaction and loyalty.

\section{B. Limitation}

1. Limited time of research and also limitations of the factors evaluated in the study.

2. The results may not be generalizable to conventional purchasing activities.

\section{Recommendations}

1. The research time should be longer.

2. Factors evaluated should be explored more and using other analytical tools to get the accuracy of the results.

\section{REFERENCES}

[1] Sukamta, "Menghadapi Era Digital,” Sindonews.com, 2017. [Online]. Available: https://nasional.sindonews.com/read/1234725/18/menghadapi-eradigital-1503955719.

[2] Isparmo, "Data Statistik Pengguna Internet Indonesia Tahun 2016," Internet Marketing, 2016. [Online]. Available: http://isparmo.web.id/2016/11/21/data-statistik-pengguna-internetindonesia-2016/.

[3] D. Amanah and D. A. Harahap, "Comparing Prices and Service Quality on Lazada and Tokopedia in Indonesia," Int. J. Latest Eng. Manag. Res., vol. 03, no. 09, pp. 19-24, 2018.

[4] D. Amanah, R. Hurriyati, V. Gaffar, L. A. Wibowo, and D. A. 
Harahap, "Perilaku store switching dalam berbelanja online," in Prosiding Seminar Nasional \& Konferensi Forum Manajemen Indonesia (FMI 9) 2017, Semarang, 2017, no. 9, pp. 1-8.

[5] D. A. Harahap and D. Amanah, "Perilaku Belanja Online di Indonesia : Studi Kasus," J. Ris. Manaj. Sains Indones., vol. 9, no. 2, pp. 193-213, 2018.

[6] E. J. Blocher, K. H. Chen, and T. W. Lin, Cost Management: A Strategic Emphasis, 2nd ed. London: Mc Graw Hill Companies Inc, 2002.

[7] S. Wanti, Taufiqurrahman, and D. D. Rahayu, "Analisis strategi keunggulan bersaing dengan pendekatan analisis SWOT pada Spartan Gym Pekanbaru," JOM Fekon, vol. 1, no. 2, pp. 1-15, 2014.

[8] M. C. Stephen P. Robins, Management, vol. 40, no. 6. 2012

[9] P. Kotler and K. L. Keller, Marketing Management. 2012.

[10] G. Blokdyk, SWOT Analysis:A Clear and Concise Reference. California: CreateSpace Independent Publishing Platform, 2018.

[11] R. Yaraddi, Advanced Swot Analysis of E Commerce Startups in Karnataka State. New Delhi: Educreation Publishing, 2018.

[12] B. Gibis et al., "Application of strengths, weaknesses, opportunities and threats analysis in the development of a health technology assessment program," Health Policy (New. York)., vol. 58, no. 1, pp. 27-35, 2001.

[13] B. L. Delahaye, Strategic Human Resource Develoment. Milton: John Wiley \& Sons, 2000.

[14] A. L. Lerner, "Strategic Planning for Higher Education," J. Higher Educ., vol. 52, no. 5, p. 470, 1981

[15] K. K. Hor and N. M. Smith, Reader-friendly strategic management. a delightful blend of academic learning and street-smart practices. Malaysia: Pelanduk Publications, 1999.

[16] G. Johnson, K. Scholes, and R. Whittington, Exploring Corporate Strategy. England: Pearson Education Limited, 2008.

[17] L. Horn, F. Niemann, C. Kaut, and A. Kemmler, SWOT Analysis And Strategic Planning - a manual. Hamburg: GFA Consulting Group, 1994.

[18] K. McGuire, SWOT Analysis 34 Success Secrets - 34 Most Asked Questions on SWOT Analysis-What You Need to Know. Tennessee: Lightning Source, 2014.

[19] D. Amanah, "SWOT Analysis Of The Wildlife Park Of Medan, Indonesia," Int. J. Econ. Commer. Manag. United Kingdom, vol. III, no. 10 , pp. $500-509,2015$.

[20] A. Haris, "Dan Strategi Pemasaran Berbasis Analisis Swot," $J$. EcoBuss, vol. 1, no. 1, pp. 1-13, 2013.

[21] F. R. David and F. R. David, Strategic Management : A Competitive Advantage Approach, Concepts and Cases. England: Pearson Education Limited, 2017.

[22] A. Verbeke and H. Merchant, Handbook of Research on International Strategic Management. Cheltenham: Edward Elgar Publishing Limited, 2012.

[23] A. Nag, Strategic Management:Analysis, Implementation, Control. India: Vikas Publishing House Pvt Ltd., 2015.

[24] R. Godfrey, Strategic Management:A Critical Introduction. Abingdon: Routledge, 2015.

[25] P. N. Gooderham, B. Grogaard, and K. Foss, Global Strategy and Management. Cheltenham: Edward Elgar Publishing, 2019.

[26] N. Siggelkow and C. Terwiesch, Connected Strategy:Building Continuous Customer Relationships for Competitive Advantage. Brighton: Harvard Business Review Press, 2019.

[27] G. Johnson, Exploring Strategy:Text and Cases, 12th ed. London: Pearson Education Limited, 2019.

[28] T. Wunder, Rethinking Strategic Management:Sustainable Strategizing for Positive Impact. Berlin: Springer Nature, 2019.
[29] D. R. Hansen and M. M. Mowen, Cost Management: Accounting And Control, 4th ed. Cincinnati, OH: South-Western Publishing, 2002.

[30] B. Hariadi, Strategi Manajemen: Strategi Memenangkan Perang Bisnis. Malang: Penerbit Bayumedia Publishing, 2003.

[31] C. W. Hofer and D. Schendel, Strategy Formulation: Analytical Concepts. St. Paul: West Publishing Company, 1978.

[32] G. Sadri and B. Lees, "Developing corporate culture as a competitive advantage," J. Manag. Dev., vol. 20, no. 10, pp. 853-859, 2001.

[33] S. Garth, A. Shepard, and J. Podolny, Strategic Management. New York: John Wiley \& Sons, 2001.

[34] J. Magretta, Understanding Michael Porter: The Essential Guide to Competition and Strategy. Boston: Harvard Business Press, 2011.

[35] R. G. McGrath, The End of Competitive Advantage: How to Keep Your Strategy Moving as Fast as Your Business. Boston: Harvard Business Press, 2013.

[36] R. Huggins and H. Izushi, Competition, Competitive Advantage, and Clusters: The Ideas of Michael Porter. New York: Oxford University Press, 2011.

[37] A. Davis and M. C. Le Merle, Blockchain Competitive Advantage:Whether You Are an Entrepreneur, Investor, Or Established Company, Learn How to Win the Battle for Blockchain Competitive Advantage. United States: Fifth Era Media, 2019.

[38] S. Alvarez, J. Manuel, P. Ruiz, and J. Manuel, Handbook of Research on Entrepreneurial Leadership and Competitive Strategy in Family Business. Pennsylvania: IGI Global, 2019.

[39] S. Muhammad, Manajemen Strategik: Konsep dan Kasus. Yogyakarta: UPP AMP YKPN, 2013.

[40] P. Kotler and G. Armstrong, Principles of Marketing. London: Pearson Education, 2016.

[41] S. Wu, Wu, Sun. 2019. Strategy for Executives. California: Moppet Books, 2019.

[42] S. M. Hassan, A. J. Sistani, and R. S. Raju, “Top Online Shopping ECompanies and their Strength and Weakness (SWOT)," Res. J. Recent Sci., vol. 3, no. 9, pp. 102-107, 2014.

[43] G. Walker and T. L. Madsen, Modern Competitive Strategy, 4th ed. New York: Mc Graw Hill Education, 2016.

[44] M. Gupta, C. Shri, and A. Agrawal, "Strategy Formulation for Performance Improvement of Indian Corrugated Industry: An Application of SWOT Analysis and QSPM Matrix," J. Appl. Packag. Res., vol. 7, no. 3, pp. 60-75, 2015.

[45] K. Sveiby, "A knowledge-based theory of the firm to guide in strategy formulation," J. Intellect. Cap., vol. 2, no. 4, pp. 344-358, 2001.

[46] O. C. Ferrell and M. D. Hartline, Marketing Strategy: Text and Cases, 6th ed. USA: South-Western, Cengage Learning, 2014.

[47] T. Hill and R. Westbrook, "SWOT Analysis: It's Time for a Product Recall," Long Range Plann., vol. 30, no. 1, pp. 46-52, 1997.

[48] D. W. Pickton and S. Wright, "What' s swot in strategic analysis?," Strateg. Chang., vol. 7, no. April, pp. 101-109, 1998.

[49] A. A. Thompson, M. A. Peteraf, J. E. Gamble, and A. J. Strickland III, Crafting \& Executing Strategy, The Quest for Competitive Advantage: Concepts and Readings, 20th ed. New York: Mc Graw Hill Education, 2016.

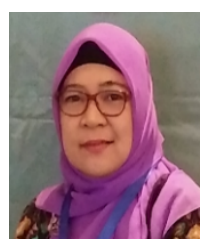

Dita Amanah is a Associate Professor in Faculty of Economics, Universitas Negeri Medan, Indonesia. Earned the undergraduate degree (Management) from Universiti Kebangsaan Malaysia in 1996. Continued masters degree also at Universiti Kebangsaan Malaysia and completed in 1999 to get MBA. Get the doctorate degree in 2019 at Universitas Pendidikan Indonesia, Bandung, Indonesia.Over 19 years of professional experience as a lecturer and researcher majoring in marketing management at Universitas Negeri Medan, Indonesia.

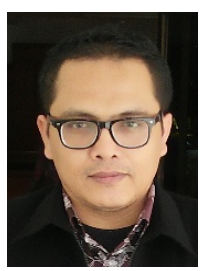

Dedy Ansari Harahap earned his undergraduate degree (Agronomy) from Universitas Muhammadiyah Sumatera Utara, Indonesia in 1998. He continued study at Universitas Syiah Kuala, Banda Aceh, Indonesia in 2006 to get MM degree and get his doctorate degree in Management Science from Universitas Pendidikan Indonesia, Bandung, Indonesia in 2019. He has over 12 years of professional experience in in bankingand is now a lecturer in management study program at Faculty of Economics and Business, Universitas Islam Bandung, Indonesia. 